Available online at GSC Online Press Directory

GSC Biological and Pharmaceutical Sciences

e-ISSN: 2581-3250, CODEN (USA): GBPSC2

Journal homepage: https://www.gsconlinepress.com/journals/gscbps

(RESEARCH ARTICLE)

\title{
Phytochemical screening and antioxidant activity of methanolic extract of Ocimum sanctum Linn. Leaves
}

\author{
Harichandan SS Priyadarshini ${ }^{1}$, Sahu Ajay Kumar ${ }^{2,}{ }^{*}$, Gautam Sakshi ${ }^{3}$ and Nemani Rahul 4 \\ ${ }^{1}$ Department of Biotechnology, Berhampur University, Berhampur, Odisha, 760007. \\ ${ }^{2}$ Department of Microbiology, Bangalore University, Bangalore, Karnataka, 560043. \\ ${ }^{3}$ Department of Biotechnology, Lovely Professional University, Punjab, India. \\ ${ }^{4}$ Department of Microbiology, Kristu Jayanti College, Bangalore.
}

Publication history: Received on 12 July 2019; revised on 06 August 2019; accepted on 09 August 2019

Article DOI: https://doi.org/10.30574/gscbps.2019.8.2.0131

\begin{abstract}
The phytochemicals present in plants are responsible for preventing disease and promoting health have been studied extensively to establish their efficacy and to understand the underlying mechanism of their action. Such studies have included identification and isolation of the chemical components, establishment of their biological potency both by in vitro and in vivo studies in experimental animals and through epidemiological and clinical-case control studies in man. Study findings suggest that phytochemicals may reduce the risk of coronary heart disease by preventing the oxidation of low density lipoprotein (LDL) cholesterol, reducing the synthesis or absorption of cholesterol, normalizing blood pressure and clotting, and improving arterial elasticity. Phytochemicals may detoxify substances that cause cancer. They appear to neutralize free radicals, inhibit enzymes that activate carcinogens, and activate enzymes that detoxify carcinogens. They observed that, the Ocimum sanctum Linn has also been suggested to possess, anticancer, antidiabetic, anti-fertility, antifungal, antimicrobial, cardio protective, analgesic, antispasmodic and adaptogenic actions. Eugenol (1-hydroxy-2methoxy-4-allylbenzene) is the active constituents present in Ocimum sanctum Linn. Indian traditional shrub tulsi (Ocimum sanctums): They unique medicinal plant. They observed that, Ocimum sanctum heals many diseases chronically due to its chemical constituent and believes that it has anti- ageing, immunomodulatory property along with antimicrobial and anticancer property. Phytochemical analysis of aqueous extract of Ocimum sanctum. They observed that, the plant is known to possess antiseptic, analgesic, anti-inflammatory, antimicrobial, antistress, immunomodulatory, hypoglycemic, hypertensive and antioxidant properties. The dried powder of Tulsi $(100 \mathrm{~g})$ was placed in the thimble of Soxhlet apparatus.500 $\mathrm{ml}$ of distilled water was used as a solvent.
\end{abstract}

Keywords: Ocimum sanctum Linn; Phytochemical analysis; Methanol extract; Antioxidant activity

\section{Introduction}

India is well known as an "Emporium of medicinal plants". It possesses about 8\% of the estimated biodiversity of the world with around 12600 species and is one of the 12 mega biodiversity centers with 2 hot spots of biodiversity in the Western Ghats and North-eastern region [1]. It's also rich in ethnic diversity, there are about 67.37 million tribal people belonging to 537 tribal groups living in different geographical locations with various subsistence patterns [2]. These tribal groups living in diverse, rich areas possess a wealth of knowledge and skills on the utilization and conservation of food and medicinal plants [3]. According to the World Health Organization (WHO), almost 65\% of the world's population has incorporated the value of plants as a methodology of medicinal agents into their primary modality of health care. It is often noted that $25 \%$ of all drugs prescribed today come from plants [4]. This estimate suggests that plant derived drugs make up a significant segment of natural product- based pharmaceuticals [5].

\footnotetext{
${ }^{*}$ Corresponding author

E-mail address: Sahuajaykumar355@gmail.com
} 
Plants have long been used by men for their basic needs especially Ocimum sanctum. In essence have been in practices of medicinal plants are deeply rooted in the society of indigenous community [6]. Medicinal plants begins an important aspect of various traditional medicine systems, have been used therapeutically all around the world [7]. Although the various systems of traditional medicine in the world, e.g., Ayurveda, Chinese traditional medicine, Unani, Tibetan Medicine [8], Amazonian or African Medicine, may be based on different theoretical and cultural models, they all integrate phytotherapy into their doctrine [9]. According to World Health Organization (WHO) estimates, more than $80 \%$ of the people in developing countries depend on the traditional medicine for their countries depend on the traditional medicine for their primary health needs [10]. It is generally estimated that over 6000 traditional plants in India are used in folk and herbal medicine, representing about $75 \%$ of the medicinal needs of the $3^{\text {rd }}$ world countries [11].

Aromatic plants possess odorous volatile substances which occur as essential oil, gumexudate, balsam and oleoresin in one or more parts, namely root, wood, bark, stem, foliage, flower and fruit. [12].The characteristic aroma is due to a variety of complex chemical compound. The essential oil is concomitant to fragrance or perfumes because these fragrance are oily in nature and they represent the essence or the active constituents of the plant [13]. They are called volatile or ethereal oils as they evaporate when exposed to air at ordinary temperatures. Essential oils are highly concentrated, low volume, high value products. Application of essential oils in agriculture as antifeedants, repellents, botanical insecticides, natural herbicides and growth booster are still open to fascinating realms of research [14]. Essential oils of only about 500 species are known in some detail at present. Of these about 50 species find use as commercial source of essential oils and aroma chemicals, through the number of those having regular and large scale utilization hardly exceeds two drones [15].

Phytochemicals (from the Greek word phyto, meaning plant) are biologically active, naturally occurring chemical compounds found in plants, which provide health benefits for humans further than those attributed to macronutrients and micronutrients[16]. They protect plants from disease and damage and contribute to the plant's color, aroma and flavor. In general, the plant chemicals that protect plant cells from environmental hazards such as pollution, stress, drought, UV exposure and pathogenic attack are called as phytochemicals [17]. Recently, it is clearly known that they have roles in the protection of human health, when their dietary intake is significant. More than 4,000 phytochemicals have been catalogued and are classified by protective function, physical characteristics and chemical characteristics and About 150 phytochemicals have been studied in detail. In wide-ranging dietary phytochemicals are found in fruits, vegetables, legumes, whole grains, nuts, seeds, fungi, herbs and spices. Broccoli, cabbage, carrots, onions, garlic, whole wheat bread, tomatoes, grapes, cherries, strawberries, raspberries, beans, legumes, and soy foods are common sources. [18]. Phytochemicals accumulate in different parts of the plants, such as in the roots, stems, leaves, flowers, fruits or seeds. Many phytochemicals, particularly the pigment molecules, are often concentrated in the outer layers of the various plant tissues. Levels vary from plant to plant depending upon the variety, processing, cooking and growing conditio. Phytochemicals are also available in supplementary forms, but evidence is lacking that they provide the same health benefits as dietary phytochemicals [19].

\subsection{Phytochemistry and medicinal properties}

According to data summarized by Meagher and Thomson, genistein prevents the formation of new capillaries that are needed for tumor growth and metastasis. The physiologic properties of relatively few phytochemicals are well understood and more many researchers have focused on their possible role in preventing or treating cancer and heart disease. [20]. Phytochemicals have also been promoted for the prevention and treatment of diabetes, high blood pressure, and macular degeneration. While phytochemicals are classified by function, an individual compound may have more than one biological function serving as both an antioxidant and antibacterial agent. Bioactive and Disease preventing phytochemicals present in plant are shown in Table 1. 
Table1 Bioactive phytochemicals in medicinal plants

\begin{tabular}{|c|c|c|}
\hline Classification & Main groups of compounds & Biological function \\
\hline $\begin{array}{l}\text { NSA } \\
\text { (Non-starch poly- } \\
\text { saccharides.) }\end{array}$ & $\begin{array}{l}\text { Cellulose, hemicellulose, gums, } \\
\text { mucilages, pectins, lignins }\end{array}$ & $\begin{array}{l}\text { Water holding capacity, delay in nutrient } \\
\text { absorption, binding toxins and bile acids }\end{array}$ \\
\hline $\begin{array}{l}\text { Antibacterial } \quad \& \\
\text { Antifungal }\end{array}$ & Terpenoids, alkaloids, phenolics & $\begin{array}{l}\text { Inhibitors of micro-organisms, reduce the risk } \\
\text { of fungal infection }\end{array}$ \\
\hline Antioxidants & $\begin{array}{l}\text { Polyphenolic compounds, flavonoids, } \\
\text { carotenoids, tocopherols, ascorbic acid }\end{array}$ & $\begin{array}{l}\text { Oxygen free radical quenching, inhibition of } \\
\text { lipid peroxidation }\end{array}$ \\
\hline Anticancer & $\begin{array}{l}\text { Carotenoids, polyphenols, curcumine, } \\
\text { Flavonoids }\end{array}$ & $\begin{array}{l}\text { Inhibitors of tumor, inhibited development of } \\
\text { lung cancer, anti-metastatic activity }\end{array}$ \\
\hline $\begin{array}{l}\text { Detoxifying } \\
\text { Agents }\end{array}$ & $\begin{array}{l}\text { Reductive acids, tocopherols, phenols, } \\
\text { indoles, aromatic isothiocyanates, coumarins, } \\
\text { flavones, carotenoids, retinoids, cyanates, } \\
\text { phytosterols }\end{array}$ & $\begin{array}{l}\text { Inhibitors of procarcinogen activation, } \\
\text { inducers of drug binding of carcinogens, } \\
\text { inhibitors of tumourogenesis }\end{array}$ \\
\hline Other & $\begin{array}{l}\text { Alkaloids, terpenoids, volatile flavor } \\
\text { compounds, biogenic amines }\end{array}$ & $\begin{array}{l}\text { Neuropharmacological agents, anti- oxidants, } \\
\text { cancer chemoprevention }\end{array}$ \\
\hline
\end{tabular}

\subsection{Antioxidants and health maintenance}

The body has several mechanisms to counteract oxidative stress by producing antioxidants, either naturally generated in situ (endogenous antioxidants), or externally supplied through foods (exogenous antioxidants). The roles of antioxidants are to neutralize the excess of free radicals, to protect the cells against their toxic effects and to contribute to disease prevention [21].

\subsection{Antioxidant Process}

When an antioxidant destroys a free radical, this antioxidant itself becomes oxidized. Therefore, the antioxidant resources must be constantly restored in the body. Thus, while in one particular system an antioxidant is effective against free radicals, in other systems the same antioxidant could become ineffective. Also, in certain circumstances, an antioxidant may even act as a pro-oxidant e.g. it can generate toxic ROS/RN. The antioxidant process can function in one of two ways: chain-breaking or prevention. [22]. For the chain-breaking, when a radical releases or steals an electron, a second radical is formed. The last one exerts the same action on another molecule and continues until either the free radical formed is stabilized by a chain-breaking antioxidant (vitamin C, E, carotenoids, etc), or it simply disintegrates into an inoffensive product. The classic example of such a chain reaction is lipid peroxidation. For the preventive way, an antioxidant enzyme like superoxide dismutase, catalase and glutathione peroxidase can prevent oxidation by reducing the rate of chain initiation, e.g., either by scavenging initiating free radicals or by stabilizing transition metal radicals such as copper and iron. [23].

\subsection{Antioxidant supplementation: advantages and inconveniences}

Antioxidant supplements are compounds obtained either by extraction from natural foods or by chemical synthesis. Of course, they do not have the same composition as natural antioxidants in foods. Therefore, opinions are divided over whether or not antioxidant supplements offer the same health benefits as antioxidants in foods. Even if antioxidant supplementation is receiving enthusiastic debate and is increasingly adopted in many industrial countries, supporting evidence is still ambiguous. Although many epidemiological data suggest that antioxidants may have a beneficial effect on many chronic diseases, the systematic use of supplements is hindered by several factors: the lack of prospective and controlled studies, the long-term effects and the dosages necessary for each type of diseases. Also, antioxidant supplements can act as pro-oxidants e.g. as oxidative stress inducers if they are consumed at levels significantly above the recommended dietary intakes (RDI). Like conventional medicines, dietary supplements may cause side effects, or interaction with another medication or supplement, that may make the health worse. However, dietary supplements can become necessary and useful in some particular situations, such as soldiers in front, sailors in ships, patients with gastrointestinal disorders, or people with low incomes, e.g. people who cannot afford a variety of vegetables, fruits, and/or sea foods. In these cases, taking one or two multivitamin with mineral tablets and fish oil capsules in RDI concentrations may be helpful to maintain good health. Taking supplements in high doses can be harmful and always 
consult a healthcare professional about combining a dietary supplement with a conventional medical treatment. If possible, it is best to get the antioxidants from a diet rich in fruits and vegetables rather than from supplements.

Tulsi is a sacred plant of Hindu religion worshipped all over the India. Tulsi means 'incomparable one' or 'matchless one' and is derived from Sanskrit. Ocimum sanctum (Family Labiatae) is a many branched, erect, stout and aromatic herb about $75 \mathrm{~cm}$ high. This small herb is found throughout India and is cultivated, worshiped in temples and houses of Hindus. This is commonly known as Vishnu-Priya, Tulsi in Sanskrit, and Kala Tulsi in Hindi and India's Holy Basil in English.

Table 2 Systematic classification

\begin{tabular}{ll}
\hline Kingdom & Plantae \\
\hline Division & Mangoliophyta \\
Class & Mangoliopsida \\
Order & Lamiates \\
Family & Labiatae \\
Genus & Ocimum \\
Species & O. santum linn \\
\hline
\end{tabular}

\subsection{Morphology}

It is erect, branched fragmented shrub with the height of about $30-60 \mathrm{~cm}$ when mature. Its leaves are simple, aromatic, branched, opposite, obtuse, elliptical and have dentate margins. They are up to $5 \mathrm{~cm}$ long. Flowers are elongate raceme in close whorls and purple in colour. Seeds are radish yellow and fruits are small. It is planted after rainy season and harvested after few months.

\subsection{Phytochemical Constituents}

The chemical composition of Tulsi is highly complex, containing many nutrients and other biologically active compounds, the proportions of which many vary considerably between strains and even among plants within the same field. Furthermore, the quantity of many of these constituent is significantly affected by differing growing, harvesting, processing and storage conditions that are not yet well understood.

The nutritional and pharmacological properties of the whole herb in its natural form, as it has been traditionally used, used result from synergistic interaction of many different active phytochemicals. Consequently the overall effects of Tulsi cannot be fully duplicated with isolated compounds or extracts. Because of its inherent botanical and biochemical complexity, Tulsi standardization has, so far, eluded modern science.

\subsection{Therapeutic Properties}

Some of the basils are a rich source of key nutrients like Vitamin A, Vitamin C, calcium and phosphorus. The presence of Vitamin A helps in strengthening eyesight. Basils also contain antioxidants like beta carotene that help in preventing cell damage."Tulsi" or the holy basil is famous throughout the globe for its healing and other medicinal properties. Its leaves are helpful in sharpening memory and in curing fever and common cold. They also act as an anti stress agent and also help in purifying blood. This, in turn, helps in reducing the risk of heart attacks and also lowers the cholesterol level. The leaves of the basil are also effective in reducing mouth ulcer and other infections of the mouth.

\subsection{Anticancer activity}

Anti-melanoma activity of 50\% alcoholic aqueous leaf extract of different species of Ocimum was studied by. Leaf extract administered orally $(200 \mathrm{mg} / \mathrm{kg}$, p.o.) resulted in significant reduction in tumor volume, increase in average body weight, and survival rate of mice.

\subsection{Anti-inflammatory activity}

Ocimum sanctum's methanolic extract $(500 \mathrm{mg})$ proved the inflammatory activity in rats. Fixed oil and linolenic acid present in tulsi have the ability to block cycloxygenase and lipoxygenase pathways of arachidonic acid metabolism. Therefore they show anti-inflammatory activities against PGE2, leukotrines induce edema in rats.Ocimum sanctum 
aqueous extract $(200 \mathrm{mg} / \mathrm{kg}$ or $400 \mathrm{mg} / \mathrm{kg})$ showed significant activity $(\mathrm{P}<0.05)$ in rats induced with carrageenan paw edema. This showed that effect of 0 . sanctum was better than indomethacine (STD drug).

\section{Materials and methodology}

\subsection{Collection and processing of plant material}

The plant material of Ocimum Sanctum was collected in the month of March 2019 from the local area of Berhampur, Odisha, India. The selected plant part removed and then washed under running tap water to remove dirt. The plant sample was then oven dried at $60^{\circ} \mathrm{C}$ for few days and was crushed in to powder and stored in polythene bags for future use.

\subsection{Preparation of plant extract}

Measured plant part was extracted with methanol and ethanol by using soxhlet apparatus method. Finally, all extracts were evaporated in a water bath to obtain the respective extracts and stored in a freeze condition at $-20^{\circ} \mathrm{C}$ until used for future analysis. Percent of yield was calculated as follows;

$$
\text { Yield } \%=\left(\mathrm{W}_{2}-\mathrm{W}_{1}\right) / \mathrm{W}_{0} \times 100
$$

Where, $\mathrm{W}_{2}=$ the weight of the extract and container, $\mathrm{W}_{1}=$ the weight of the container alone and $\mathrm{W}_{0}=$ the weight of the initial dried sample.

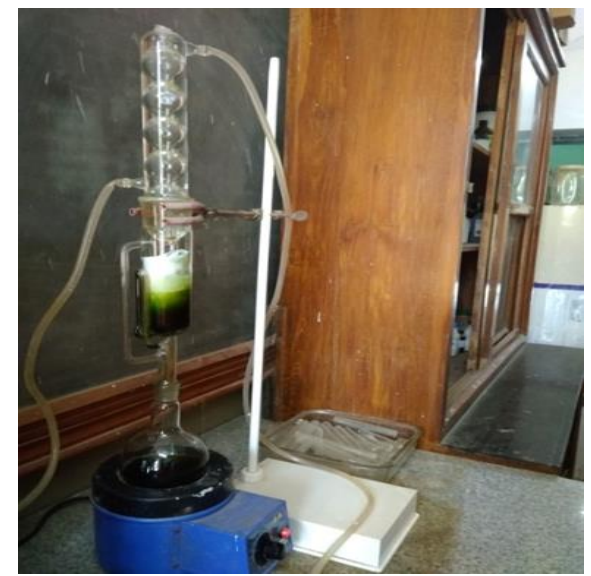

Figure 1 Plant extract preparation

\subsection{Chemicals reagents}

All chemicals and reagents used during the research work were of sandard grade. Mayer's reagents, Iodine solution, Felhing's solution A and B, Ammonia solution, Isoamyl alcohol, glacial acetic acid, Folin-Ciocalteu reagent, sodium carbonate, Gallic acid, rutin, DPPH(1,1-Diphenyl 2-Picrylhydrazyl), Absorbic acid,FeSO ${ }_{4}$ Nicotinamide Adenine Dinuleotide (NADH), Tris HCL Buffer, Phosphate Buffer, Sodium phosphate, Ammonium molybdate, $\mathrm{HNO}_{3}, \mathrm{Choloform}$ , $\mathrm{AlCl}_{3}, \mathrm{HCL}, \mathrm{NaOH}, \mathrm{H}_{2} \mathrm{SO}_{4}, \mathrm{FeCl}_{3}, \mathrm{Methanol}$, and ethanol.

\subsection{Qualitative analysis of phytochemicals}

Quantitative analysis of methanolic extract was extract carried out to determine the process of the various bioactive compounds using the standard quantitative procedure.

\subsubsection{Test for alkaoids}

To $1 \mathrm{ml}$ of extract added $1 \mathrm{ml}$ of Mayer's reagent and few drop of Iodine solution. Formation of yellow colour precipitate indicates the presence of alkaloids. 


\subsubsection{Test for terpenoids}

To $1 \mathrm{ml}$ of crude extract add $1 \mathrm{ml}$ of concentrated $\mathrm{H}_{2} \mathrm{SO}_{4}$ and heated 2 minutes.A greyish colour indicates the presence of terpeniods.

\subsubsection{Test for phenol and tannins}

To $1 \mathrm{ml}$ of crude extract added $2 \%$ of $1 \mathrm{ml}$ of $\mathrm{FeCl}_{3 . A}$ blue green or black colour indicates presence of phenol and tannins.

\subsubsection{Test for reducing sugar}

To $1 \mathrm{ml}$ of crude extract added $1 \mathrm{ml}$ of Felhing's A solution and $1 \mathrm{ml}$ of Felhing's B solution. Formation of red colour indicates the presence of sugar.

\subsubsection{Test for saponin}

To $1 \mathrm{ml}$ of extract added $2 \mathrm{ml}$ of distilled water, shaken well and formation of $1 \mathrm{~cm}$ layer of form indicates presence of Saponin.

\subsubsection{Test for protein}

To $1 \mathrm{ml}$ of extract added few drop of $\mathrm{HNO}_{3}$.Formation of yellow colour indicates the presence of protein.

\subsubsection{Test for steroid}

$1 \mathrm{ml}$ of extract mixed with $1 \mathrm{ml}$ of chloroform and concentrated $\mathrm{H}_{2} \mathrm{SO}_{4}$ sidewise.A red colour presence at the lower chloroform layer indicates presence of steroids.

\subsubsection{Test for anthocyanin}

$2 \mathrm{ml}$ of extract is added to $2 \mathrm{ml} 2 \mathrm{~N} \mathrm{HCL}$ and $\mathrm{NH}_{3}$ the appearance of pink red turns blue violet indicates presence of Anthocyanin.

\subsubsection{Test for coumarin}

$3 \mathrm{ml}$ of $10 \% \mathrm{NaOH}$ was added to $2 \mathrm{ml}$ of extract formation of yellow colour indicates presence of coumarin.

\subsubsection{Test for leucoantocyanin}

$5 \mathrm{ml}$ of isoamyl alcohol added to $5 \mathrm{ml}$ of aqueous extract, upper layer appear red in colour indicates the presence of lecoanthocyanin.

\subsubsection{Test for glycosides}

$1 \mathrm{ml}$ plant extract treated with $2 \mathrm{ml}$ glacial acetic acid containing a drop (2-3)of Fecl 3 .A brown colour ring indicates the presence of positive test.

\subsection{Quantitative phytochemical analysis}

\subsubsection{Estimation of total phenolic content (TPC)}

The concentration of phenolic in plant extracts were determined by Folin-Ciocalteu method with little modification. $20 \mu \mathrm{l}$ of methanolic extract $(1 \mathrm{mg} / \mathrm{ml})$ in to a test tube and add $1.58 \mathrm{ml}$ of distill water then add $7 \%$ of $100 \mu \mathrm{l}$ FolinCiocalteu's reagent. Wait for $8 \mathrm{mins}$, then $10 \%$ of $300 \mu \mathrm{l}$ of saturated sodium carbonate solution $(250 \mathrm{~g} / \mathrm{l})$ was added. Incubated the solution for 2 hour at room temperature, the absorbance was measured at $765 \mathrm{~nm}$ in triplicate. Gallic acid(10-500 mg/l) was used for calibration of standard curve. The results were expressed as milligram gallic acid equivalent (mg GA/g) dry weight of plant materials.

\subsubsection{Estimations of total flavnoid content (TFC)}

The total flavonoid content was estimated by Spectrophotometric method. The crude extract contained $1 \mathrm{ml}$ of the methanol solution of the extract in $\mathrm{mg} / \mathrm{ml}$ concentration and $1 \mathrm{ml}$ of $2 \% \mathrm{AlCl}_{3}$ solution dissolved in methanol. The solution was incubated for an hour at room temperature. The absorbance was obtained at $415 \mathrm{~nm}$ in triplicate. The 
same protocol was repeated for standard solution of rutting and standard curve was constructed. Then, the content of flavonoid in the extract was expressed in term of rutting equivalent (mg of RE/g) dry weight of plant material.

\subsection{DPPH radicals scavenging activity}

The free radical scavenging capacity of the methanolic extracts was determined by using DPPH assay. DPPH solution $(0.004 \% . \mathrm{w} / \mathrm{v})$ was prepared in methanol. Stock solution $(1 \mathrm{mg} / \mathrm{ml})$ of methanolic extract of plant and standard ascorbic acid $(0.05 \mathrm{~g} / \mathrm{ml})$ were prepared using methanol. Various concentration $(10-500 \mu \mathrm{g} / \mathrm{mL})$ of the plant extract and ascorbic were taken in test tube $1 \mathrm{ml}$ freshly prepared DPPH solution were added, the test tubes were protected from light by covering with aluminum foil. The final volume in each test tube was made to $2 \mathrm{ml}$ with methanol and incubated in dark for 30 mins at room temperature. After incubation the absorbance was read at $517 \mathrm{~nm}$ using a spectrophotometer. Control sample was prepared containing the same volume of method and DPPH without any extract and reference ascorbic acid. Methanol was served as blank. The radical scavenging was calculated by the following formula;

\%Inhibition $=[($ Abs of control- Abs of sample $) /$ Abs of control $] \times 100$

\subsubsection{Superoxide anion radical scavenging activity}

This assay was based on the reduction of nitro blue tetrazolium (NBT) in the presence of nicotinamide adenine dinucleotide (NADH) and phenazine methosulfate (PMS) under aerobic condition. Tris $\mathrm{HCl}$ buffer (3ml, 16mM, pH 8.0) containing $1 \mathrm{~mL}$ NBT $(50 \mu \mathrm{M})$ solution $1 \mathrm{~mL}$ NADH $(78 \mu \mathrm{M})$ solution and a sample solution of extract $(10-500 \mu \mathrm{g} / \mathrm{mL}) \mathrm{in}$ distill water mixed. The reaction was incubated $25^{\circ} \mathrm{C}$ for $5 \mathrm{~min}$, and the absorbance was read at $560 \mathrm{~nm}$ against the corresponding blank samples. Ascorbic acid was used as a standard .The decreased absorbance of reaction mixture indicated increased superoxide anion scavenging activity.

\subsection{Statistical analysis}

All the experimental measurements were carried out in triplicate and are expressed as average of three analysis \pm standard deviation (SD).Linear regression analysis was used to calculate the $\mathrm{IC}_{50}$ value.

\section{Results}

\subsection{Yield percentage}

The table 2 yield percentage of methanolic plant extracts of Ocimum sanctum was respectively.

Table 2 Yield percentage (\%) of methanolic plant extract of Ocimum sanctum

\begin{tabular}{lllll}
\hline Plant extract & $\begin{array}{l}\text { Wt. of extract and } \\
\text { container in } \mathbf{g}\left(\mathbf{w}_{\mathbf{2}}\right)\end{array}$ & $\begin{array}{l}\text { Wt. of container } \\
\text { along in } \mathbf{g}\left(\mathbf{w}_{\mathbf{1}}\right)\end{array}$ & $\begin{array}{l}\text { Wt. of initial dried } \\
\text { sample in } \mathbf{g}\left(\mathbf{W}_{\mathbf{0}}\right)\end{array}$ & Yields \% \\
\hline Methanol & $110.43 \mathrm{~g}$ & 166.43 & 12.9 & 29.45 \\
\hline
\end{tabular}

\subsection{Qualitative screening of phytochemicals}

The preliminary phytochemicals screening of Ocimum sanctum leaves were done to identify various bioactive compounds. In these screening process alkaloida, tannis, phenol, saponins, glycosides, steroid, Coumarin, anthocyanin, protein, terpenoids and Leucoanthocyanin shows different types of results in solvent i.e., methanol. The results of phytochemical screening of Ocimum sanctum are as presented in table 3.

The leaves extract gives positive results for alkaloids, terpenoids, phenol and tannin, steroid, coumarin, glycosides in the methanolic solvent. While reducing sugar, saponins, Leucoanthocyanin were shows negative result in the methanolic solvents. 
Table 3 Phytochemical screening of methanolic extracts of 0 . Sanctum

\begin{tabular}{lll}
\hline $\begin{array}{l}\text { Sr. No. } \\
\text { number }\end{array}$ & Bioactive compound & $\begin{array}{l}\text { Methanolic } \\
\text { extract }\end{array}$ \\
\hline 1 & Alkaloids & + \\
2 & Trepenoids & + \\
3 & Phenol and Tannins & + \\
4 & Reducing Sugar & - \\
5 & Saponins & - \\
6 & Proteins & - \\
7 & Streoids & + \\
8 & Anthocyanin & - \\
9 & Coumarin & + \\
10 & Leucoanthocyanin & - \\
11 & Glycosides & + \\
\hline
\end{tabular}

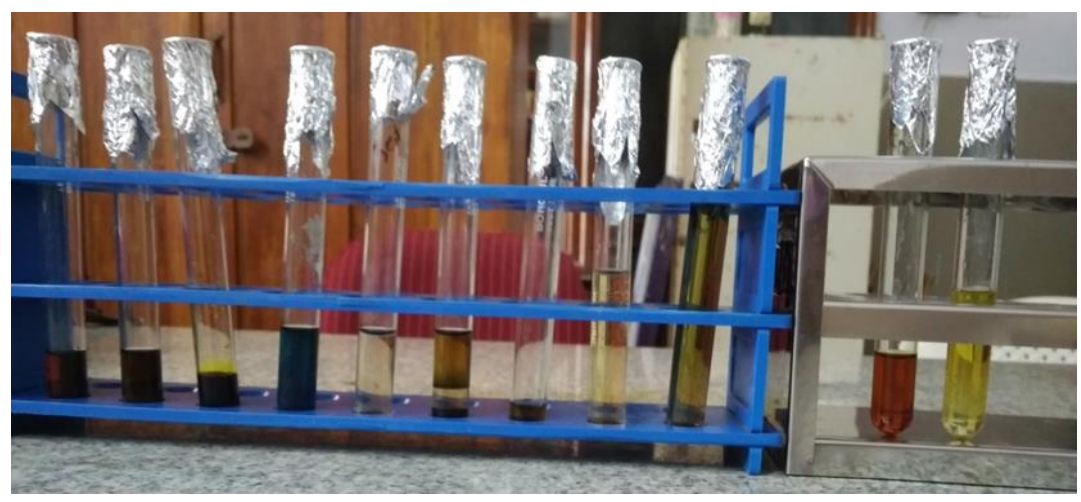

Figure 2 Indicates qualitative phytochemical analysis of methanolic Leave extract of Ocimum sanctum.

\subsection{Qualitative test of phytochemicals}

\subsubsection{Estimation of total phenolic contents (TPC)}

The total phenolic content of both solovent extract of Ocimum sanctum were measured by Folin- Ciocalteu reagent The plant extracts were examined from the regression equation expressed in gallic acid equivalent(GAE) and the strandard curve $\mathrm{Y}=0.001 \mathrm{x}+0.0029, \mathrm{R}^{2}=0.977$ equation The total phenolic content of plant extract were $102.12 \mathrm{mg} / \mathrm{g}$ methanol respectively.

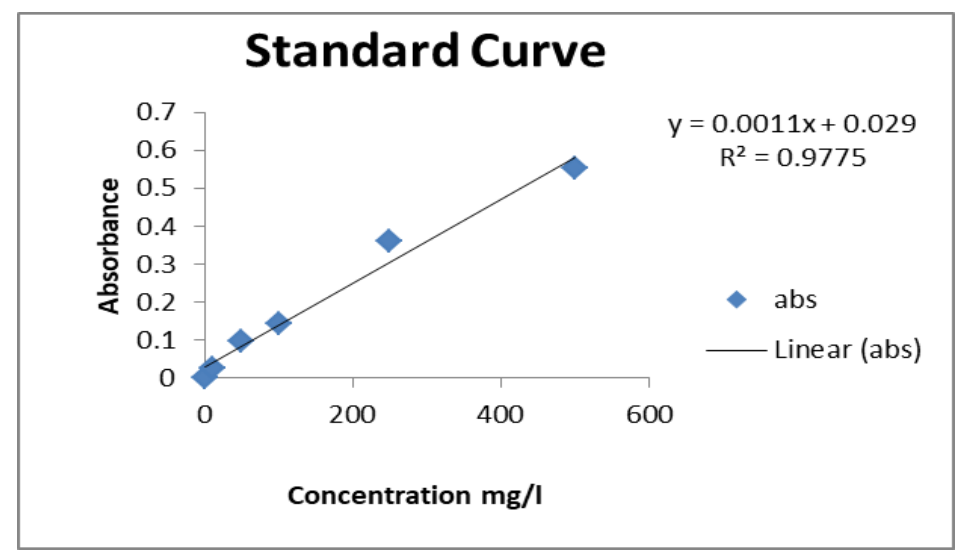

Figure 3 The standard curve of total phenolic content (TPC) 


\subsubsection{Estimation of total flavonoid content (TFC)}

The extraction of total flavonoid contents of plant extract were determined by using spectrophotometric method with aluminum chloride. The total flavonoids content were expressed in terms of rutin equivalent (RE) (regression equation of calibration curve: $\left.\mathrm{Y}=0.001 \mathrm{x}+0.006, \mathrm{R}^{2}=0.941\right) \mathrm{mg}$ of $\mathrm{RE} / \mathrm{g}$ of extracts.

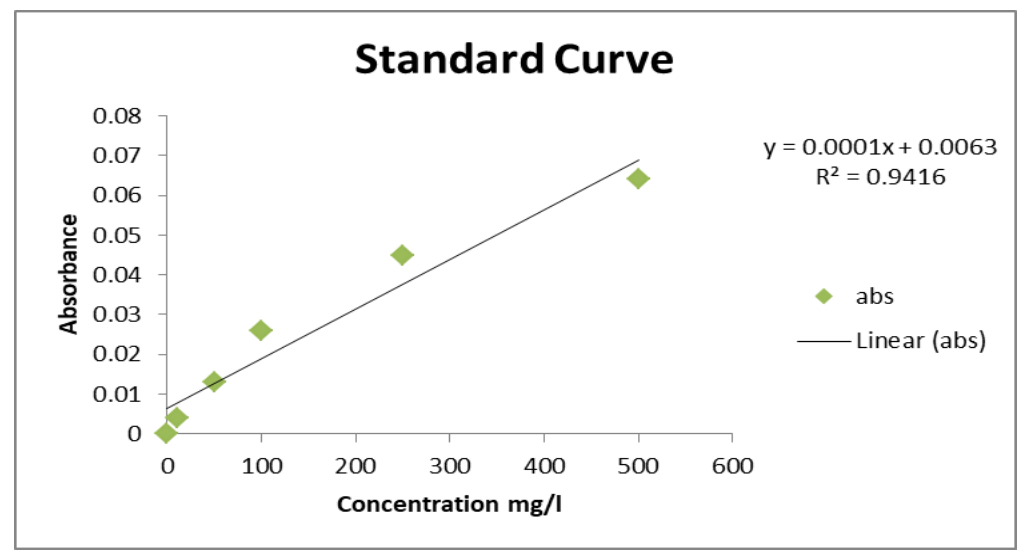

Figure 4 The standard curve of total flavonoid content (TFC)

Table 4Total phenolic and flavonoid content of methanolic plant extracts were expressed in mg/g.

\begin{tabular}{ccc}
\hline Plant Extract & $\begin{array}{l}\text { Total phenolic content } \mathbf{m g} / \mathbf{g}, \\
\text { plant extract in }\end{array}$ & $\begin{array}{l}\text { Total flavonoid content } \mathbf{~ m g} / \mathbf{g}, \\
\text { plant extract in } \mathbf{R E}\end{array}$ \\
\hline Methanolic & 102.12 & 146.634
\end{tabular}

The flavonoid content of the plant extracts were calculated as rutin equivalent and value were 146.634 in e methanol respectively.

\subsection{Antioxidant activity}

\subsubsection{DPPH (1, 1 Diphenyl-2-picrylhydrazyl radical) scavenging activity}

The methanolic leaves extracts of 0 . sanctum had strong antioxidant activity against all the free radicals investigated. The DPPH radical is widely used in assessing free radical scavenging activity was $65.75 \%$ in methanol respectively at a concentration of $500 \mu \mathrm{g} / \mathrm{mL}$ leaves extracts. In other hand, that of the control ascorbic acid was $88.52 \%$ at a concentration of $500 \mu \mathrm{g} / \mathrm{mL}$.

Table 5 DPPH radical scavenging activity of methanolic extract of O.sanctum and ascorbic acid value s are expressed as mean \pm standard deviation $(n=3)$

\begin{tabular}{lll}
\hline Conc. $\boldsymbol{\mu g} / \mathbf{~ m L}$ & Ascorbic acid & Plant extract methanol \\
\hline 10 & $48.02 \pm 0.0040$ & $19.86 \pm 0.0030$ \\
50 & $55.25 \pm 0.0035$ & $35.78 \pm 0.0032$ \\
100 & $69.20 \pm 0.0016$ & $50.12 \pm 0.0010$ \\
250 & $76.65 \pm 0.0039$ & $60.33 \pm 0.0015$ \\
500 & $88.52 \pm 0.0031$ & $67.75 \pm 0.0031$ \\
\hline
\end{tabular}




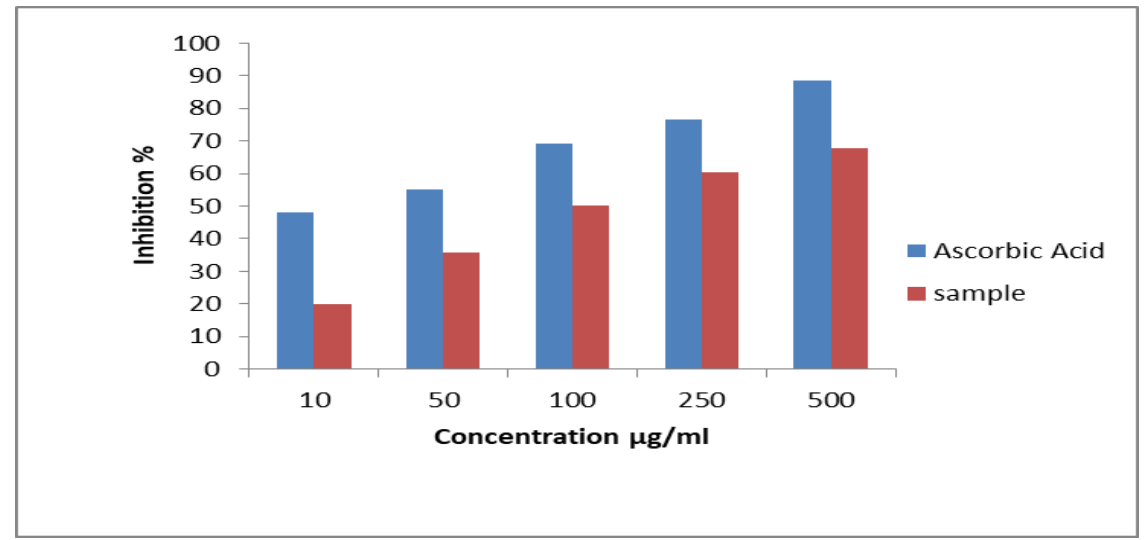

Figure 5 DPPH radical scavenging activity of methanolic extracts of Ocimum sanctum and ascorbic acid values are expressed as mean \pm standard deviation $(n=3)$

\subsubsection{Superoxide radical scavenging activity}

Superoxide is a reactive oxygen species that can damage cell and DNA, leading to various diseases. This assay was determined by NBT assay and the value range from $12.04 \%$ to $60.160 \%$ methanol leaves extract respectively at a concentration $10-500 \mu \mathrm{g} / \mathrm{mL}$. While that of the control, ascorbic acid the inhibition percentage ranges from $10 \mu \mathrm{g} / \mathrm{mL}$ to $500 \mu \mathrm{g} / \mathrm{mL}$.

Table 6 Superoxide radical scavenging activity of methanolic extract of 0 . Sanctum and ascorbic acid values are expressed as mean \pm standard deviation $(\mathrm{n}=3)$

\begin{tabular}{ccl}
\hline Conc. $\boldsymbol{\mu g} / \mathbf{m l}$ & Ascorbic Acid & Plant extract methanol \\
\hline 10 & $20.625 \pm 0.030$ & $12.040 \pm 0.012$ \\
50 & $30.766 \pm 0.025$ & $15.640 \pm 0.052$ \\
100 & $55.123 \pm 0.060$ & $20.060 \pm 0.010$ \\
250 & $64.286 \pm 0.035$ & $35.865 \pm 0.060$ \\
500 & $72.630 \pm 0.035$ & $60.160 \pm 0.058$ \\
\hline
\end{tabular}

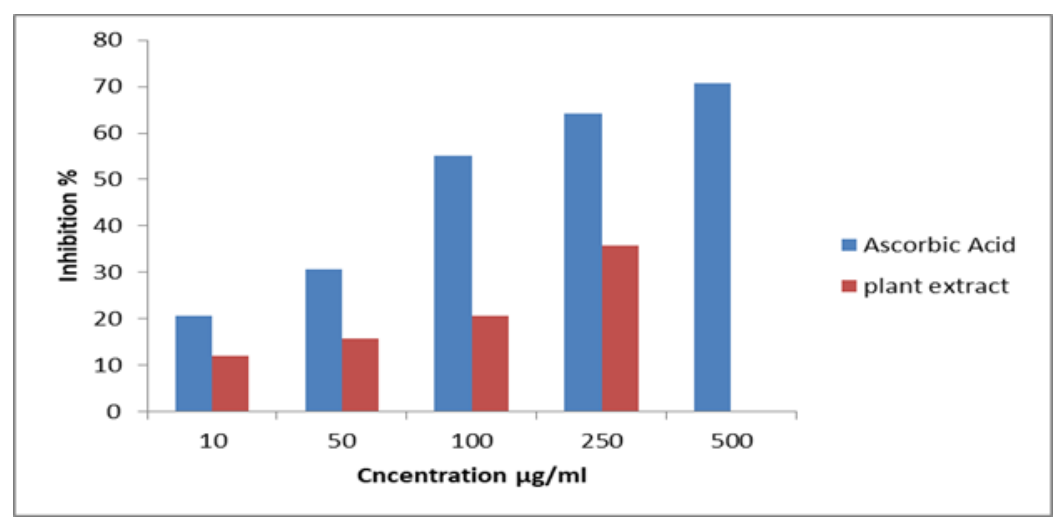

Figure 6 Superoxide radical scavenging activity of methanolic extracts of Ocimum sanctum and ascorbic acid values are expressed as mean \pm standard deviation.

\section{Discussion}

The results are dealt holistically on the basis of biological endpoint beginning with plant extract, yield percentage, qualitative and quantitative test and antioxidant properties. The selected plant parts were extracted with $300 \mathrm{~mL}$ methanol via Soxhlet apparatus. 


\subsection{Phytochemical analysis}

Plants are important source of potentially useful structures for the development of new chemotherapeutic agents. The pharmacological action of crude drugs and other therapeutic uses are due to their therapeutically active constituents. So the preliminary phytochemical analysis revealed the importance of secondary metabolites. From this analysis Methanolic leaf powder extracts were found to have more chemical constituents compared to other extracts. Quantitative Analysis Free radicals are chemical entities that can exist individually with one or more unpaired electrons. The generation of free radicals can bring about thousands of reactions and thus cause extensive tissue damage. Lipids, proteins and DNA are all susceptible to attack by free radicals. There is a evidence that phytochemical could be used as effective antioxidants for improving human .Free radical scavenging action is an important attribute of antioxidants which is measured by the DPPH radical scavenging activity. In Ocimum sanctum Methanolic extract exhibit strong antioxidant activity compared to that of the standard compound BHT (Butylated Hydroxy Toulene). Hence this investigation suggested that the plant naturally having rich source of antioxidants could be used in the prevention of free radical diseases.

\section{Conclusion}

Tulsi is also known as "the elixir of life" since it promotes longevity. Different parts of plant are used in Ayurveda and Siddha Systems of Medicine for prevention and cure of many illnesses and everyday ailments like common cold, headache, cough, flu, earache, fever, colic pain, sore throat, bronchitis, asthma, hepatic diseases, malaria fever, as an antidote for snake bite and scorpion sting, flatulence, migraine headaches, fatigue, skin diseases, wound, insomnia, arthritis, digestive disorders, night blindness, diarrhea and influenza. This review will definitely help for the researchers as well as clinicians dealing with Ocimum sanctum to know its proper usage as this herb is seemed to be highly valuable, possessing many pharmacological/ medicinal properties. In conclusion, the present study phytochemical screening, total phenolic contents, total flavonoids contents and antioxidant properties have been done using Ocimum sanctum plant of methanol extracts. Among the two extract, the methanol was found to be the best extract the antioxidant.

\section{Compliance with ethical standards}

\section{Acknowledgments}

We gratefully acknowledge to our principle of Berhampur University and head of department life science for allowing performing all the experiment on laboratory, and also thanks to Mrs. Sakshi find the plant sample.

\section{Disclosure of conflict of interest}

The authors declare that there are no conflicts of interest.

\section{References}

[1] Amuthavalluvan V. (2011) Ethno medicinal practices and traditional healing system of Kattunayakan in Tamilnadu: An anthropological study, Int Mult Res J, 1[7], 47-51.

[2] Shanmugam S, Rajendran K and Suresh K. (2012).Traditional uses of medicinal plants among the rural people in Sivagangai district of Tamil Nadu, Southern India, Asian Pac J Trop Biomed, [5], 429-S434.

[3] Ranganathan R, Vijayalakshmi R and Parameswari P. (2103). Ethnomedicinal survey of Jawadhu hills in Tamil Nadu, Asian J Pharm Clinical Res, 5[2].

[4] Johnsy G, Davidson S and KaviyarasanV. (2011). Indigenous knowledge of medicinal plants used for the treatment of skin diseases by the kaani tribe of Kanyakumari district, Int Pharm Pharmaceut Sci, [4], 1.

[5] Farnsworth NR, Akerele 0, Bingel AS, Soejarto DD and Guo Z. (2014). Medicinal plants in therapy, Bull WHO, 63[6], 965-981.

[6] Farnsworth NR and Morris RW. (1996). Higher plants-the sleeping giant of drug development, Am. J. Pharm. Sci. Support. Public Health, 148[2], 46-52.

[7] Raskin I and Ripoll C. (2013). Can an apple a day keep the doctor away? Curr. Pharm. Des., 10[27], $3419-3429$. 
[8] Hasler CM and Blumberg JB. (1996) Symposium on phytochemicals: biochemistry and physiology. Journal of Nutrition, [129], 756S-757S.

[9] Gibson EL, Wardel J and Watts CJ. (1998). Fruit and Vegetable Consumption, Nutritional Knowledge and Beliefs in Mothers and Children Appetite, [31], 205-228.

[10] Mathai K. Nutrition in the Adult Years (2001). In Krause's Food, Nutrition, and Diet Therapy, 10 ${ }^{\text {th }}$ ed., ed. L.K. Mahan and S. Escott-Stump, [271], 274-275.

[11] American Cancer Society. (2003).

[12] Meagher E, Thomson C. Vitamin and Mineral Therapy. (1993). In Medical Nutrition and Disease, 2nd ed., G Morrison and L Hark, Malden, Massachusetts: Blackwell Science Inc, [33], 58.

[13] King A and Young G. (1999).Characteristics and occurrence of phenolic phytochemicals. Journal of the American Dietetic Association, 99(2), 213-218.

[14] Narasinga Rao. (2003). Bioactive phytochemicals in Indian foods and their potential in health promotion and disease prevention. Asia Pacific Journal of Clinical Nutrition, 12 [1], 9-22.

[15] Halliwell B and Gutteridge JMC. (2002) Free radicals in biology and medicine. 4th ed. Oxford, UK: Clarendon Press.

[16] Valko M, Izakovic M , Mazur M, Rhodes CJ, et al.(2003) Role of oxygen radicals in DNA damage and cancer incidence. Mol. Cell Biochem, [266], 37-56.

[17] Valko M, Leibfritz D, Moncola J, Cronin MD, et al.(2007) Free radicals and antioxidants in normal physiological functions and human disease. Review. Int. J. Biochem. Cell Biol, [39], 44-84.

[18] Braekke K, Harsem NK and Staff AC. (2006) Oxidative stress and antioxidant status in fetal circulation in preeclampsia. Pediatr. Res, [60], 560564.

[19] Valko M, Morris H and Cronin MTD. (2005). Metals, toxicity and oxidative stress. Curr. Med. Chem. [12], 11611208.

[20] Joseph B. (2013). Ethan pharmacological and photochemical aspects of Ocimum sanctum Linn. The elixir of life.Brit. J Pharma. Res, 3[2], 273-292.

[21] Okunade AL. (2002). Ageratum conyzoides L. (asteraceae).Fitoterapia, [73], 116.

[22] Ranganathan R, Vijayalakshmi R and Parameswari P. Ethnomedicinal survey of Jawadhu hills in Tamil Nadu, Asian J Pharm Clinical Res, 2012, 5(2).

[23] Johnsy G, Davidson S and Kaviyarasan V. Indigenous knowledge of medicinal plants used for the treatment of skin diseases by the kaani tribe of Kanyakumari district, Int Pharm Pharmaceut Sci, 2012, 4-1.

\section{How to cite this article}

Harichandan PSS, Sahu AK, Gautam S and Nemani R. (2019). Phytochemical Screening and antioxidant activity of methanolic extract of Ocimum Sanctum Linn. Leaves. GSC Biological and Pharmaceutical Sciences, 8(2), 22-33. 